\title{
Diabetic Retinopathy: Study of the Action of 0-Betahydroxyethyl-Rutosides (HR) by Retinal Fluoresceinography*
}

\author{
M. Tschopp, D. Pometta and J. BabeL
}

Clinique Universitaire de Médecine (Prof. A.F. Muller), Clinique Universitaire d'Ophtalmologie (Prof. J. Babel), Hôpital Cantonal, Genève, Suisse

Received: October 31, 1969

Summary. The action of 0 -beta-hydroxyethyl-rutosides (HR) on diabetic retinopathy has been evaluated on 20 diabetic patients by means of fluoresceinography. - The natural evolution and the evolution after treatment with HR (2400 mg orally per day) have been compared during periods of observation of 2 months. The administration of the medication and placebo, as well as the interpretation of the results, has been carried out on a double-blind basis. - The administration of HR causes a statistically significant reduction of the retinal vascular permeability to fluorescein.

Etude de l'action de l'0-beta-hydroxyethyl-rutoside $(H R)$ sur la rétinopathie diabétique par la fuorescéinographie rétinale.

Résumé. L'action de l'0-beta-hydroxyethyl-rutoside (HR) sur la rétinopathie diabétique a été évaluée chez 20 malades diabétiques au moyen de la fluorescéinographie. - L'évolution naturelle ot après traitement par HR (2400 $\mathrm{mg} / j o u r$ per os) a été comparée au cours de périodes d'observation de deux mois. L'administration du médicament et du placebo, de même que l'interprétation des résultats ont été effectuées selon la méthode du double insu. - L'administration de HR entraîne une diminution statistiquement significative de la perméabilité vasculaire à la fluorescéine.

Diabetische Retinopathie: Untersuchung der Wirkung von 0-Beta-hydroxyaethyl-Rutosiden (RH) mittels retinaler Fluorescinographie.

Zusammenfassung. Bei 20 Diabetikern wurde die Wirkung von 0-beta-hydroxyaethyl-rutosidea (HR) bei Retinopathia diabetica mit Hilfe der Fluoresceinographie geprüft. - Die natürliche Entwicklung wurde mit derjenigen unter Behandlung mit HR (2400 mg pro Tag peroral) nach Beobachtungszeiten von 2 Monaten verglichen. Die Verabreichung von Medikament und Placebo sowie die Interpretation der Resultate wurden als Doppelblind-Versuch durchgeführt. - Die Zufuhr von JER verursacht eine statistisch signifikante Senkung der vaskulären Fluorescein-Permeabilität.

Key-words: Diabetio retinopathy, vascular permeability, fluoresceinography, flavonoids.

\section{Introduction}

The problems posed by the complications of diabetes are more serious than those of the treatment of diabetes itself. According to the Public Health Service (U. S. A.) diabetes is responsible for $10 \%$ of the cases of blindness in the United States. Among these, $46 \%$ are juvenile diabetics and $54 \%$ are cases in which the diabetes appeared in adult life [18].

To these cases of blindness one must add the even more numerous cases where the visual acuity is diminished by diabetic retinopathy.

The evolution of diabetic retinopathy is difficult to assess. Viscual acuity allows an appreciation of macular function. Examination of the fundus with the direct or indirect ophthalmoscope allows only a drawing by the observer, and is therefore in part subjective. If the drawing is done with care, it involves a loss of time for the observer and the patient. Colour photography is insufficient, because it does not always show the fine lesions.

Novotny and Alvis [16] in 1961 described the first intravenous injection of fluorescein, allowing the study of the vascularization of the fundus.

Diabetic retinopathy is only one particular localization of a generalized diabetic micro-angiopathy, and

\footnotetext{
* Supported by Zyma S.A. Nyon, Switzerland.
}

the multiplicity of treatments $[2,12,13,17$ and 21] shows clearly the insufficiency of therapeutics in the face of the problems posed by diabetic retinopathy. Since 1938, when Szent-Györgyi [19] discovered "Vitamin P", the factor of vascular permeability, known today as flavonoids, several publications have suggested that the flavonoids have an effect on capillary fragility [6 and 14$]$ and permeability [14].

However, the conclusions of these publications are open to argument, for the trials were not carried out on a double-blind controlled basis. The Food and Drug Administration considers that evidence for the efficacy of flavonoids has not so far been shown, and it has announced the intention of withdrawing the authorization for their sale. In a recent editorial of the British Medical Journal [20] the authors, who share the opinion of the Food and Drug Administration, do not however exclude the possibility of an action of flavonoids in diabetic retinopathy. Some isolated reports show after treatment with 0 -beta-hydroxyethyl-rutosides $(\mathrm{HR})^{1}$ an improvement of conjunctival capillary resistance in patients suffering from diabetic retinopathy. [5, $22]$.

The aim of this study was to evaluate the action of HR on diabetic retinopathy, making allowance for the natural evolution of the illness, and avoiding subjective

1 Z 3010, Zyma 
evaluation of the course of the illness and the action of the product. With this aim the trial was carried out on a double-blind basis [3], the period of administration of placebo giving us an indication of the natural evolution of diabetic retinopathy.

\section{Method}

We examined 20 diabetic subjects (Table 1) suffering from diabetic retinopathy, 14 women and 6 men, aged from 38 to 70 years with an average age of 59 years. The lesions of the fundus were characterized

Table 1

\begin{tabular}{|c|c|c|c|c|c|}
\hline Case No. & $\mathrm{Se}$ & $\begin{array}{c}\mathrm{x} \text { Age } \\
\mathrm{yr}\end{array}$ & $\begin{array}{l}\text { Duration } \\
\text { of Dia- } \\
\text { betes } \\
\text { yr }\end{array}$ & $\begin{array}{l}\text { Duration } \\
\text { of retino- } \\
\text { pathy } \\
\text { yr }\end{array}$ & Treatment \\
\hline 1. Za. & $\mathrm{F}$ & 58 & 2 & 2 & sulphonylureas \\
\hline 2. Gri. & $\mathrm{F}$ & 69 & 8 & 7 & sulphonylureas \\
\hline 3. Bou. & $\mathrm{F}$ & 66 & 6 & 6 & sulphonylureas \\
\hline 4. Fis. & $\mathrm{F}$ & 61 & 13 & 3 & instulin \\
\hline 5. Boe. & M & 38 & 14 & 4 & insulin \\
\hline 6. Pia. & $\mathrm{F}$ & 59 & 23 & 11 & insulin \\
\hline 7. Bau. & $\mathrm{F}$ & 69 & 12 & 4 & sulphonylureas \\
\hline 8. Bie. & M & 58 & 15 & 11 & insulin \\
\hline 9. Мa. & $\mathrm{F}$ & 62 & 17 & 8 & insulin \\
\hline 10. Bov. & $\mathrm{F}$ & 70 & 12 & 4 & sulphonylureas \\
\hline 11. Th. & $\mathrm{M}$ & 63 & 15 & 5 & insulin \\
\hline 12. Ber. & $\mathrm{F}$ & 49 & 37 & 19 & insulin \\
\hline 13. Gui. & $\mathrm{F}$ & 65 & 30 & 15 & insulin \\
\hline 14. Dub. & M & 70 & 11 & 5 & insulin \\
\hline 15. Fre. & F & 58 & 11 & 5 & sulphonylureas \\
\hline 16. Phi. & M & 64 & 19 & 7 & insulin \\
\hline 17. $\mathrm{Ti}$. & $\mathrm{F}$ & 60 & 25 & 11 & insulin \\
\hline 18. Gro. & $\mathrm{F}$ & 46 & 17 & 8 & insulin \\
\hline 19. De. & $\mathrm{M}$ & 57 & 12 & 5 & insulin. \\
\hline 20. Jä. & $\mathrm{F}$ & 28 & 11 & 3 & insulin. \\
\hline
\end{tabular}

by micro-aneurysms, waxy exudates and sometimes haemorrhages. No patient presented neo-vascularization. The time of observation comprised 2 periods, each of 2 months, during which the patients received successively $\mathrm{HR}, 2$ capsules of $400 \mathrm{mg}^{1}$ three times daily, followed by placebo, or vice-versa. The state of the diabetic retinopathy was evaluated before treatment, and after 2 to 4 months evolution, by colour photographs and retinal fluorescein angiography. For the statistical analysis we used the law of F of Snedecor [11] (using a computer) and the chi square test.

\section{Technique of retinal angiography}

After dilation of the patients'pupils, at least $30 \mathrm{~min}$ before the examination [1], we administered a local skin anaesthetic (xylocaine $0.5 \%$ ) at the elbow. A "broad" intracath ${ }^{2}$ was introduced in the cephalic or basilic vein, and then passed into the sub-clavicular vein. A $0.9 \%$ saline drip was installed, to maintain the

2 Bardic R., produced by Bard-Davol Ltd., Clactonon-Sea, Essex, England. permeability of the intracath before the injection of fluorescein.

$5 \mathrm{ml}$ of fluorescein $(20 \%)$ was injected using a $10 \mathrm{ml}$ syringe, which allowed a rapid injection (1 to $2 \mathrm{sec})$ into the intracath. The first photograph was

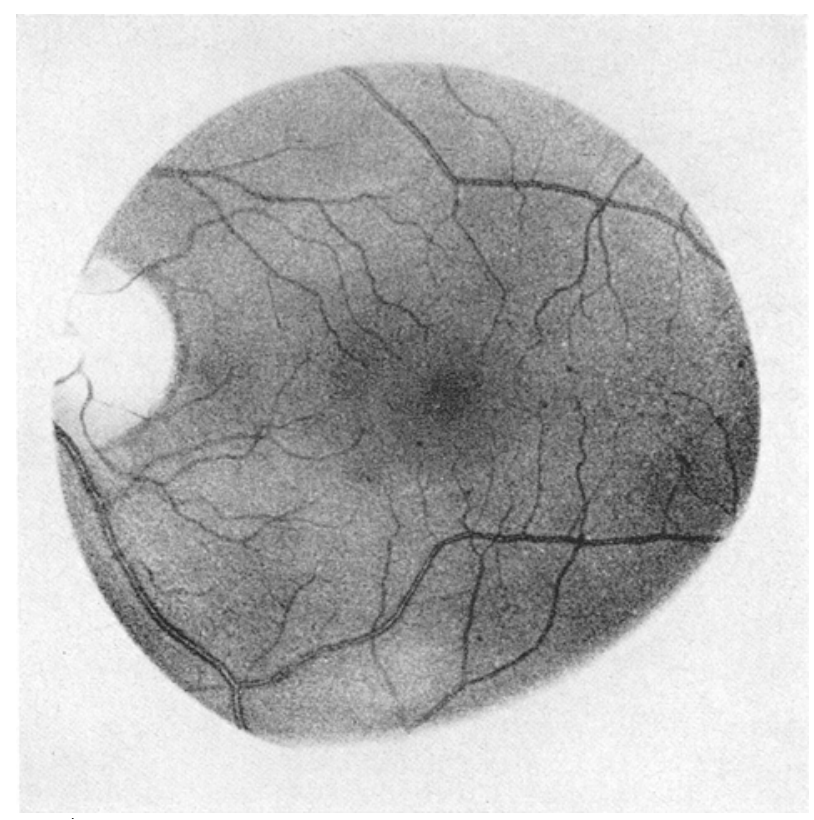

Fig. 1. Case No. 12: photograph taken at the end of the fluorescein injection. No lesion visible

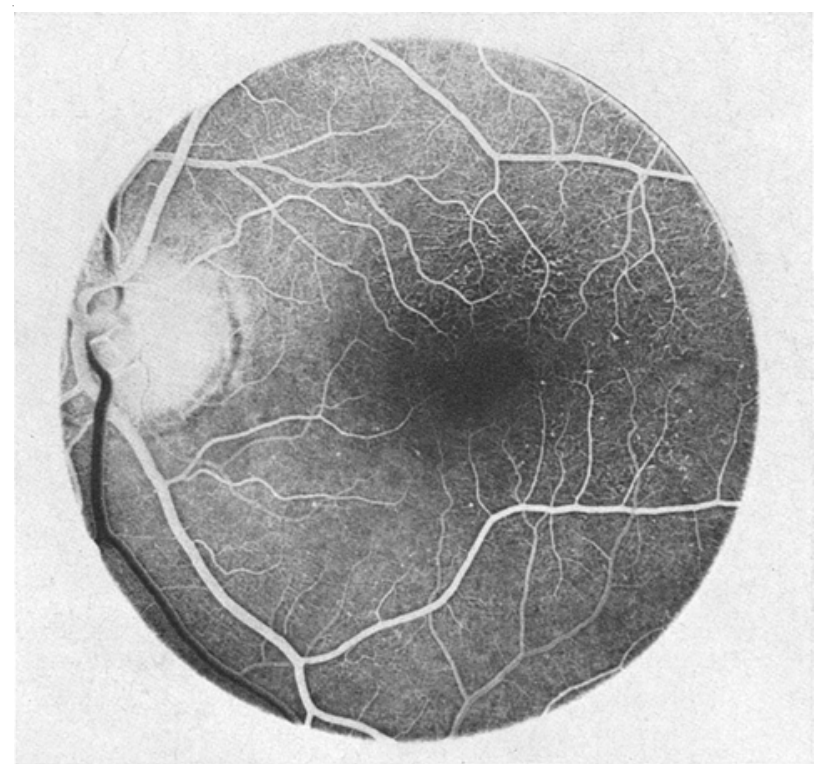

Fig. 2. Case No, 12: Arterial time. The capillary bed is clearly visible. Appearance of some micro-aneurysms

taken at the end of the injection (Fig. 1). As soon as the fluorescence appeared in the retinal arteries (Fig. 2), about 13 sec later the observer photographed the retina and took 15 pictures during the arterial and venous phase (Fig. 3), the duration of which was 
about $20 \mathrm{sec}$, and then 1 later photograph (Fig. 4) after $3-4 \mathrm{~min}$.

The photographs were taken with a Zeiss automatic retinograph equipped with a flash generator of $120-$ $240-480-720$ Joules.

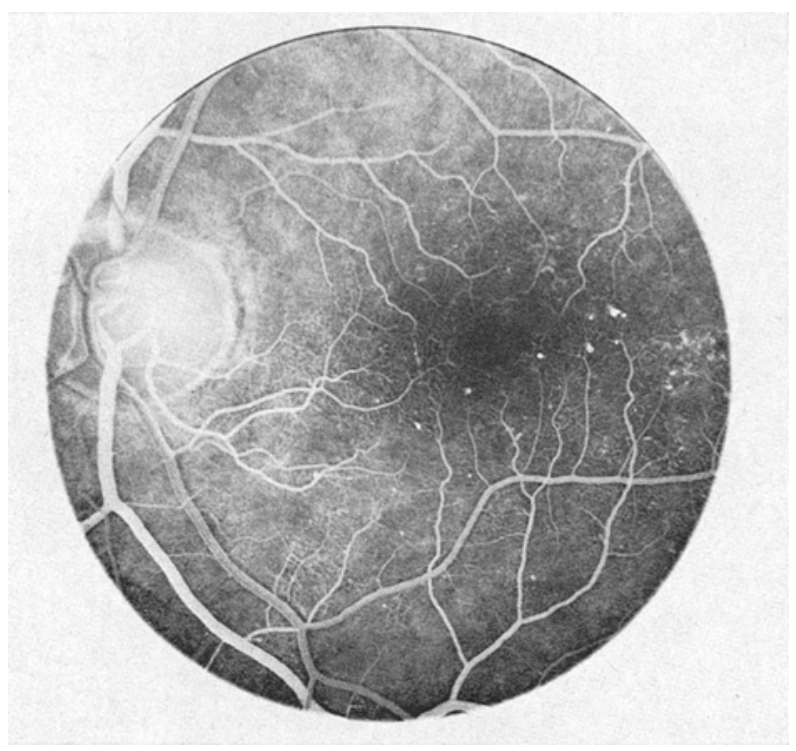

Fig. 3. Case No. 12: Venous time. The micro-aneurysms are very fluorescent. Beginning of vascular extravasation of fluorescein

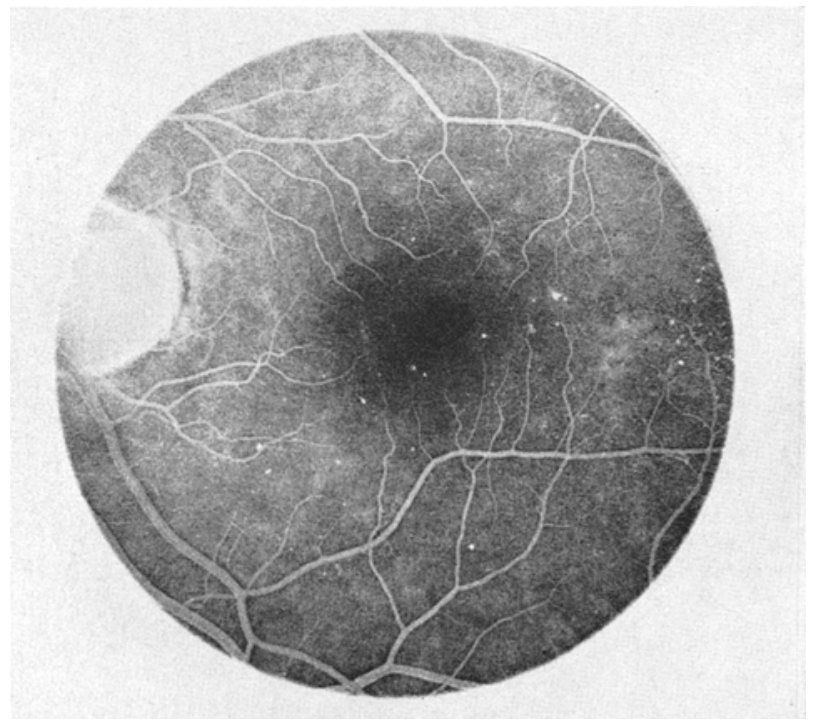

Fig. 4. Case No. 12: Late time. The vascular extravasation of fluorescein is clearly visible. The micro-aneurysms remain fluorescent for a long time after the injection

We used a power of 720 joules and an excitation filter (Kodak Wratten 47-A) combined with the stop filter GG $14.3 \mathrm{~mm}$. The photographs were made with a Plus-X-Pan 135-20 film, 22 din and developed at a temperature of $20^{\circ} \mathrm{C}$ with Agfa Rodinal developer ( $20 \mathrm{cc}$ for $400 \mathrm{ce}$ of water).
The evolution of the diabetic retinopathy was assessed during the 2 periods by means of 3 examinations [Fig. 5]. The first period was between the first and second examination, and the second between the second and third examination.

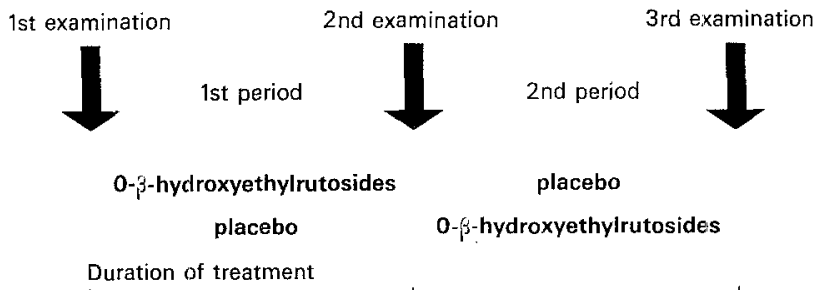

2 months

4 months Fig. 5

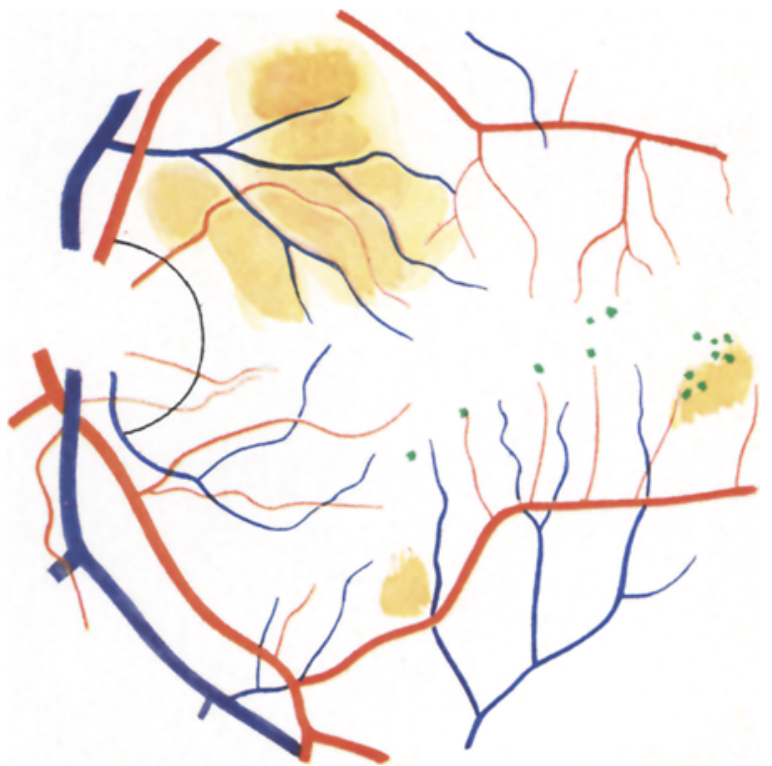

Fig. 6. Case No. 12: Synthetic schema of the fluorescein photographs of the first examination yellow: extravasated fluorescein green : micro-aneurysms

The gravity of the diabetic retinopathy was assessed by clinical examination, colour photography of the fundus and "synthetic" graphic (Fig. 6) representation of the lesions observed at the various times of fluoresceinography. These diagrams were produced by tracing the arteries and the retinal veins. The tracing paper was then super-imposed on the various fluorescein photographs, and the lesions appearing during the arterial, venous and late phases were reproduced. The comparison of the diagrams obtained (Fig. 7 and 8) at different stages of the illness offers the possibility of evaluating with precision the evolution of the diabetic retinopathy.

\section{Interpretation of the results}

The original documents and diagrams were analysed separately and independently by 3 observers, whose 
results were subsequently compared. No important disagreement was revealed between the different assessments of the evolution of the retinopathy.

The key to the study was only communicated to the experimenters after the evaluation of the evolution of the retinopathy during the 2 observation periods.

We compared the evolution after the administration of HR followed by placebo (Table 2 ) and placebo followed by HR (Table 3).

Table 2. Patients treated by 0- $\beta$-hydroxyethyl-rutosides during the 1st period and by the placebo during the 2nd period

\begin{tabular}{llll}
\hline Case No. & $\begin{array}{l}\text { Evolution } \\
\text { during the } \\
\text { 1st period }\end{array}$ & $\begin{array}{l}\text { Evolution } \\
\text { during the } \\
\text { 2nd period }\end{array}$ & $\begin{array}{l}\text { Final result: } \\
\text { comparison } \\
\text { between the } \\
\text { 1st and 3rd } \\
\text { examination }\end{array}$ \\
\hline 1. Za. & + & - & - \\
2. Gri. & + & - & - \\
3. Bou. & + & - & + \\
4. Fis. & + & - & - \\
6. Pia. & + & - & - \\
8. Bie. & 0 & - & - \\
14. Dub. & + & - & - \\
17. Ti. & + & - & - \\
18. Gro. & 0 & &
\end{tabular}

$$
\begin{aligned}
+ & =\text { improvement } \\
0 & =\text { no change } \\
- & =\text { deterioration }
\end{aligned}
$$

\begin{tabular}{|c|c|c|c|}
\hline Case No. & $\begin{array}{l}\text { Evolution } \\
\text { during the } \\
\text { 1st period }\end{array}$ & $\begin{array}{l}\text { Evolution } \\
\text { during the } \\
\text { 2nd period }\end{array}$ & $\begin{array}{l}\text { Final result: } \\
\text { comparison } \\
\text { between the } \\
\text { 1st and 3rd } \\
\text { exam. }\end{array}$ \\
\hline
\end{tabular}

Table 3. Patients treated by the placebo during the 1st period

\begin{tabular}{|c|c|c|c|}
\hline 5. Boe. & + & - & + \\
\hline 7. Bau. & - & - & - \\
\hline 9. Ma. & + & - & - \\
\hline 12. Ber. & 0 & + & + \\
\hline 13. Gui. & 0 & - & - \\
\hline 15. Fre. & + & 0 & + \\
\hline 16. Phi. & - & + & + \\
\hline
\end{tabular}
and by 0-B-hydroxyethyl-rutosides during the 2nd period

$$
\begin{aligned}
+ & =\text { improvement } \\
0 & =\text { no change } \\
& =\text { deterioration }
\end{aligned}
$$

\section{Results}

Of the 20 patients examined at the beginning, four did not take regularly the medication or the placebo and were therefore excluded from the trial.

The randomization was well balanced, since 9 patients received HR first and then placebo, and 7 patients the reverse.

The natural evolution of the diabetic retinopathy can be appreciated by the "placebo period". The comparison between the first and third examination allows assessment of the overall deterioration or not of the diabetic retinopathy, i.e. information about the final results.
During the observation period the micro-aneurysms and the hard exudates showed no characteristic modification. Following administration of HR no new haemorrhage appeared, but existing haemorrhages did not disappear. We did observe, however, variations in

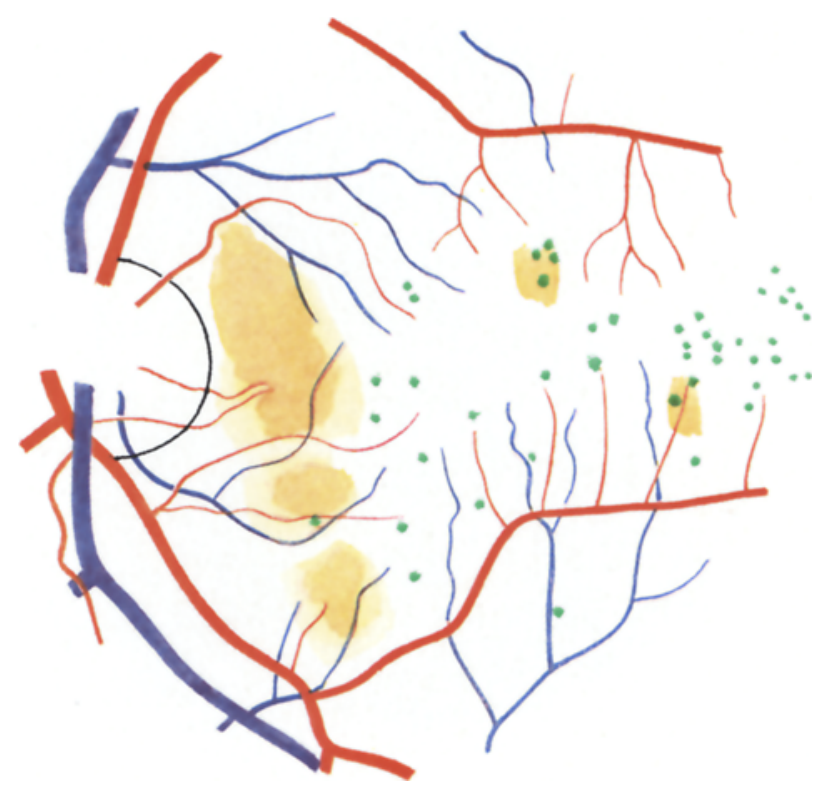

Fig. 7. Case No. 12: Synthetic schema of the fluorescein photographs of the second examination, i. $\Theta$. after 2 months administration of placebo yellow: extravasated fluorescein green : micro-aneurysms

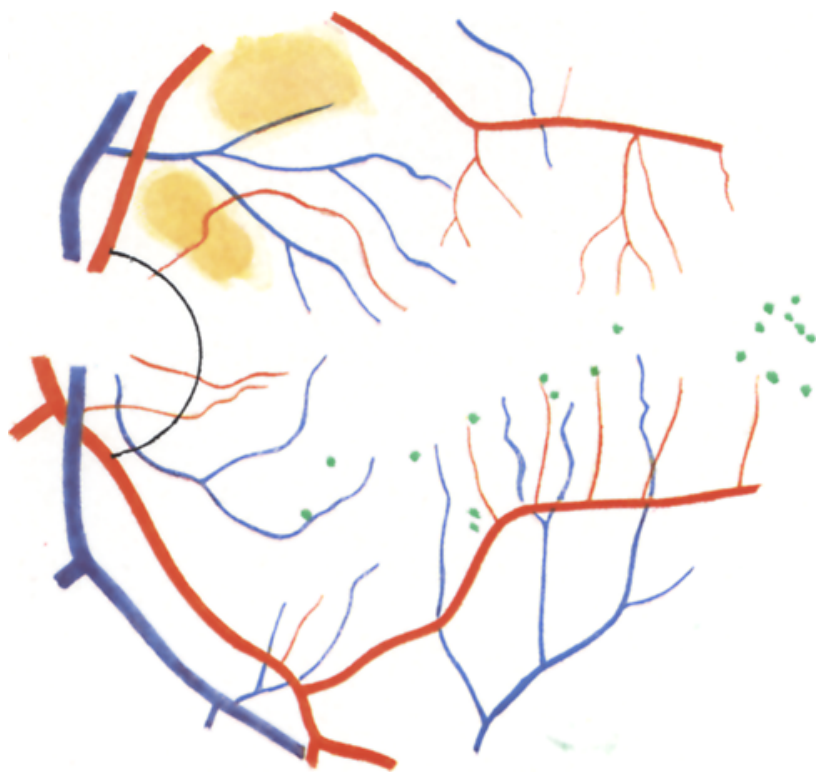

Fig. 8. Case No. 12: Synthetic schema of the fluorescein photographs of the third examination, i.e. after 2 months administration of $0-\beta$-hydroxyethyl-rutosides. One notes a marked diminution of the extravasated fluorescein yellow: extravasated fluorescein green : micro-aneurysms 
the vascular permeability to fluorescein. A halo of fluorescence formed around the vessels and the edge of the vascular wall became hazy. The changes involved particularly the quantity of fluorescein extravasated into the retinal tissue (Fig. 9 and 10).

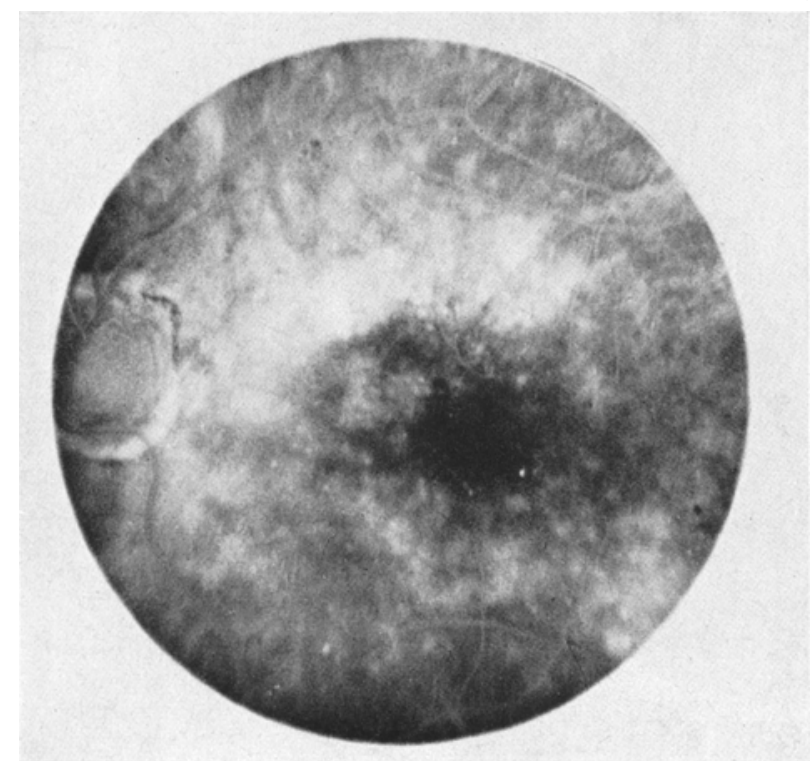

Fig. 9. Case No. 6: Venous time. At the first examination, marked extravasation of fluorescein into the retinal tissue. The fluorescein appears more brilliant, being no longer absorbed by the haemoglobin

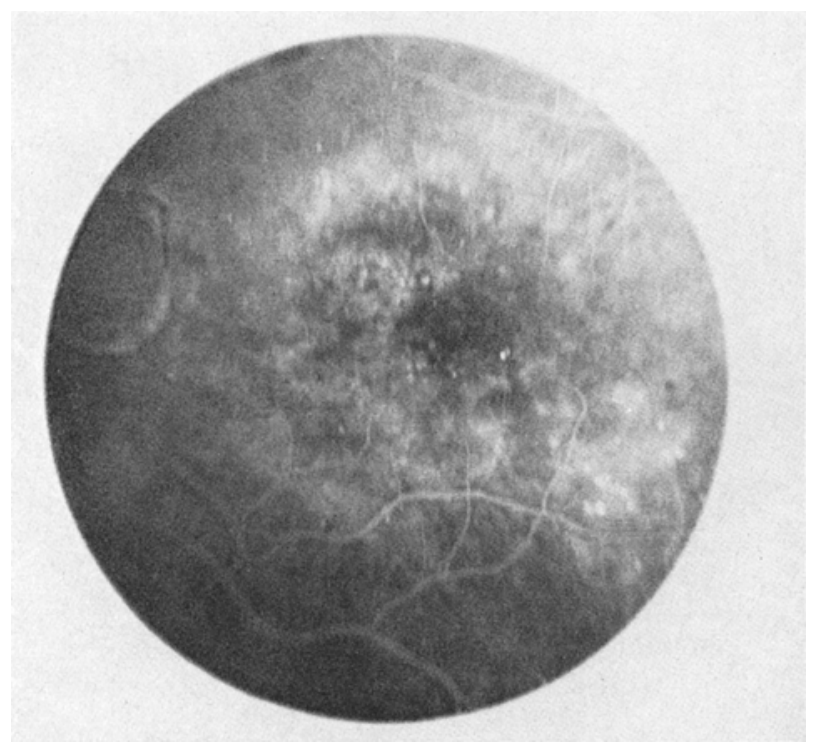

Fig. 10. Case No. 6: Venous time. At the second examination, after 2 months administration of 0 - $\beta$-hydroxyethylrutosides, the extravasated fluorescein has diminished, as compared with Fig. 10

As shown in Table 2 and 3, HR had a favourable action on the vascular permeability in 9 cases. In 3 cases there was no modification, which can be con- sidered as a favourable result since the "natural" evolution showed a deterioration of the lesions. 4 cases showed an increased permeability to fluorescein after treatment with HR.

If we compare the period of administration of HR with the placebo period, we see that the observed improvement is statistically significant since we obtain

Table 4. Natural evolution (with placebo)

\begin{tabular}{llc}
\hline Deterioration & $\begin{array}{l}\text { Improvement } \\
\text { or no change }\end{array}$ & Total \\
\hline 11 & 5 & 16 \\
\hline
\end{tabular}

Table 5. Evolution after treatment by $0-\beta$-hydroxyethylrutosides compared with the natural evolution

\begin{tabular}{|c|c|c|c|}
\hline & $\begin{array}{l}\text { natural } \\
\text { evolution } \\
\text { unfavour- } \\
\text { able }\end{array}$ & $\begin{array}{l}\text { natural } \\
\text { evolution } \\
\text { favourable } \\
\text { or no } \\
\text { change }\end{array}$ & Total \\
\hline $\left.\begin{array}{l}\text { Effect of } \\
\text { the treatment } \\
\text { with } 0 \sim \beta \text {-hy- } \\
\text { droxyethyl- } \\
\text { rutosides }\end{array}\right\}$ & $\begin{array}{r}1 \\
t \quad 10\end{array}$ & $\begin{array}{l}3 \\
2\end{array}$ & $\begin{array}{r}4 \\
12 \\
16 \\
\end{array}$ \\
\hline
\end{tabular}

12 improvements (Table 5) with HR against only 5 (Table 4) with placebo. If we consider the number of deteriorations, we find only 4 after treatment with HR (Table 5) against 11 after placebo treatment (Table 4). This difference is statistically significant (F-test of Snedecor: $P<5 \%$ ).

Since the favourable effect of HR on vascular permeability is seen during treatment, we have sought to verify whether this action also persists after stopping the HR.

HR has in fact a favourable effect only during its administration. The improvement did not persist after stopping the HR; there were 12 improvements of the vascular permeability under HR and only 6 in the final result.

As shown in Table 5, HR improved the vascular permeability of the diabetic retinopathy in 12 cases, and of particular interest, 10 improvements appeared in those cases in which the natural evolution (with placebo) was unfavourable. In only one case was the unfavourable evolution with placebo continued with H.R.

Thus, we may conclude, that during its administration, HR has a definite positive effect on the vascular permeability.

\section{Discussion}

The intravaseular fluorescence gives information on the dynamics of the retinal circulation and the morphology of the vascular tree, whereas the extravascular fluorescence is a measure of the increase in the 


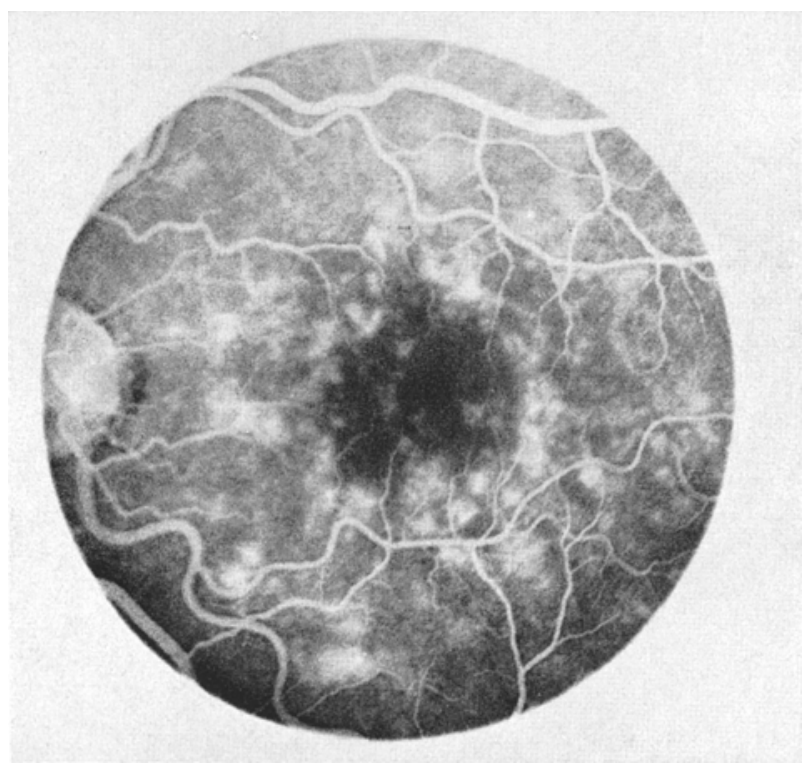

Fig. 11a. Case No. 20: Venous time. Very marked extravasation of fluorescein into the retinal tissue. Photograph taken at the first examination

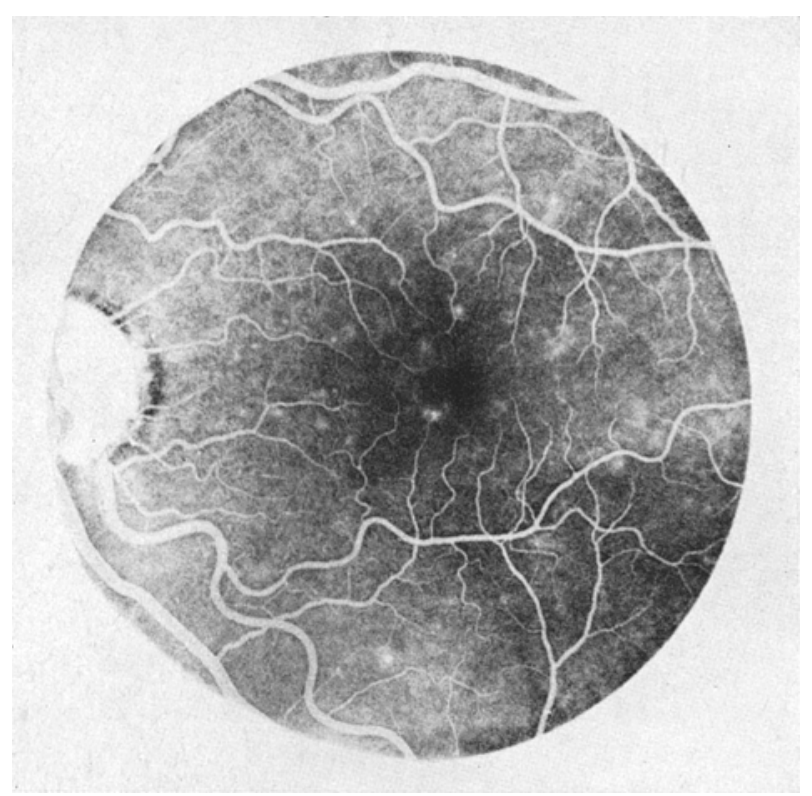

Fig. 12a. Case No. 20: Venous time. Photograph taken 1 day after the acido-ketotic coma. There is a marked diminution of fluorescein extravasation after two months administration of $0-\beta$-hydroxyethyl-rutosides

vascular permeability. The extravascular fluorescence is more brilliant than the intravascular fluorescence, which is absorbed by haemoglobin.

The fluorescein which circulates in the blood bound to albumin (7 and 8), probably crosses, in this form, the wall of the retinal vessels.

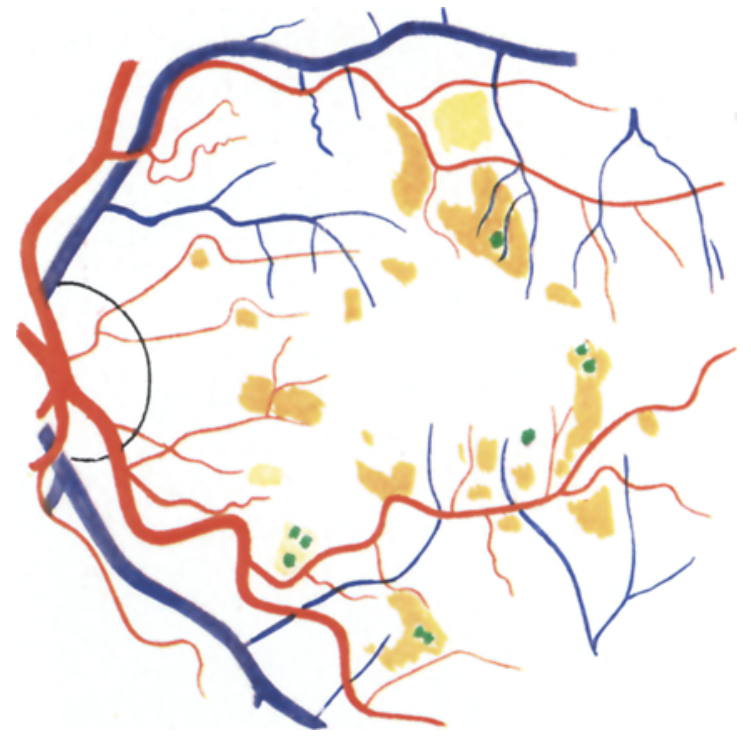

Fig. 11b. Case No. 20: Synthetic schema of the photographs of the first examination. Marked extravasation of fluorescein

yellow: extravasated fluorescein green: micro-aneurysms

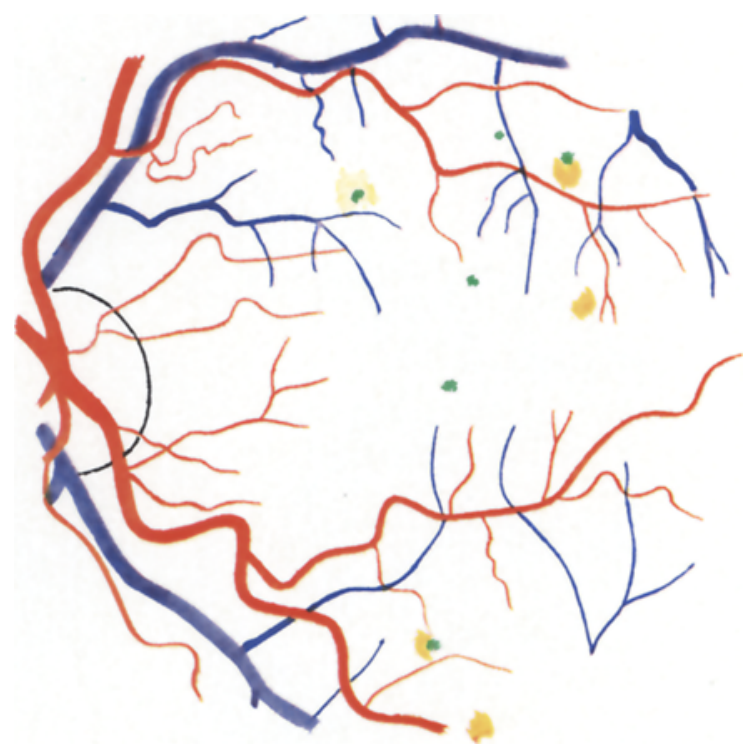

Fig. 12b. Case No. 20: Synthetic schema of fluorescein photographs of the second examination, i. e. after 2 months administration of 0 - $\beta$-hydroxyethyl-rutosides. There is a marked diminution of the vascular extravasation, in comparison with the schema of the Fig. 11a, and this in spite of the acido-ketotic coma yellow: extravasated fluorescein green : micro-aneurysms

In many publications to date the distinction has not been quite clear between capillary permeability and fragility, many of the techniques being based on a suction technique and the resistance of the capillary 
to this lowering of pressure [10]. Not only are the physiological variations from one individual to another considerable, but these methods do not determine the capillary permeability at all.

At the moment, retinal fluorescein-angiography is the only clinical method which allows an easy assessment of the vascular permeability in studies of diabetic retinopathy.

An increase of the vascular permeability in diabe. tes, particularly of long duration is already known [4, 23 ].

Certain authors $[9,15]$ have described in uncontrolled diabetes an increase of the permeability to fluorescein, which disappears after control of the diabetes.

We have excluded from the statistical analysis one patient (case No. 20), who escaped examination during the second period of the experiment, and the results of this case deserve mentioning.

At the time of the first fluoresceinography she showed a marked extravasation of fluorescein (Fig. 11a and $11 \mathrm{~b}$ ). After two months of treatment with HR this patient returned to the University Medical Clinic in acidoketotic coma due to dietary abuse. The day after admission we performed a fluoresceinography. In spite of the uncontrolled diabetes, the fluoresceinography showed a marked diminution of extravasated fluorescein (Fig. 12a and 12b), compared with the examination made 2 months earlier. This isolated observation confirms the results of our trial on the favourable action of HR on the vascular permeability.

The increase of vascular permeability has been considered as a factor favouring the appearance and deterioration of diabetic retinopathy. The effect of $\mathrm{HR}$ on the retinal capillary permeability allows one to suppose a favourable long-term action in the treatment of diabetic retinopathy, which could only be confirmed after a long-term trial. On the other hand, the action of $\mathrm{HR}$ is not prolonged after cessation of treatment.

\section{References}

1. Amalric, P.: Quelques indications nouvelles de l'angiographie fluorescéinique. Ann. Oculist. 200, 129 161 (1967).

2. Babel, J.: Le traitement de la rétinopathie diabétique par les anabolisants. Méd, et Hyg. 23, 485-486 (1965).

3. Boymond, P.: Comment préparer un essai de médicament à double insu? Journal suisse de Pharmacio 107, 109 (1969).

4. Cogan, D.G., Kuwabara, T.: Ocular Mieroangiopathy in Diabetes. In: Vascular Complication of
Diabetes mellitus, pp. 53-63. Saint-Louis: Kimura and Caygill 1967.

5. Cuendet, J.F., Sevin, R.: Rétinopathies diabétiques: possibilités et limites du traitement par des doses élevées d'un facteur $P$, le tri-hydroxyéthylrutoside. Ophthalmologica 148, 121-129 (1964).

6. Desvignes, P., Klein, M.: Expérimentation clinique de la trioxyéthylrutine dans le traitement des rétinopathies diabétiques. Inform. Thérap. 5, 9-11 (1967).

7. Dollery, C.T., Hodge, J.V.: Studies of the retinal circulation with fluorescein. Brit. med. J. 1962 II, $1210-1215$.

8. Ferrer, O.M.: Serial fluorescein fundus photography of retinal circulation. A description of technique. Amer. J. Ophthal. 60, 587-591 (1965).

9. Fraser, R.: Communication au Ve Congrès de la Fédération internationale du diabète. Toronto, $20-24$ juillet 1964.

10. Gerard, C.: Résistance capillaire conjonctivale. Etude physiologique. Thèse méd. de Naney, 1951.

11. Heller, R.: Manuel de Statistique Biologique. Paris: Gauthier-Villars 1968

12. Houtsmuller, A.J., van Poppel, A.L.: Treatment of R.D. with anabolic steroids. Ophthalmologica 145, $185-206(1963)$.

13. Ireland, J.T., Cullen, J.F., Oliver, M.F., Duncan, J.P.: A study of the effect of Atromid therapy in exsudative diabetic retinopathy. J. Atheroscler. Res. 3, 701-708 (1963).

14. Larcan, A., Cordier, J., Huriet, G., Georges, B.: Effets de la trioxyéthylrutine sur la fragilité et la perméabilité capillaires. Thérapie 20, 1259-1264 (1965).

15. Niesel, P.: Fluoreszenzangiographie des Fundus beim juvenilen Diabetes. 5e Diabetes Kolloquium, Association suisse du Diabète, Berne, ler mars 1969.

16. Novotny, H.R., Alvis, D.L.: A method of photographing fluorescence in circulation blood in the human retina. Circulation 24, 82-86 (1961).

17. Pestalozzi, D.: Zur Behandlung der R.D. mit Deeadurabolin. Ophthalmologica 147, 125-133 (1964).

18. Pometta, D., Reess, S.B.: La rétinite diabétique et son traitement par hypophysectomie. Méd. et Hyg. 22, 744-745 (1964).

19. Szent-Györgyi, A.: Z. physiol. Chemie 255, 126-130 (1938).

20. Today's Drugs. Editorial. Brit. med. J. 1969 I, $235-$ 237.

21. Valk, L.E.M.: Influence favorable du phényl-propionate de 19 -nor-androsténolone sur la rétinopathie diabétique. Bull. et mém. Soc. franc. ophtal. 72, $596-608(1959)$.

22. Vicari, S., Babel, J., Cardinet, J.: L'action du THR dans la rétinopathie diabétique. Ophthalmologica 154, 21-30 (1967).

23. Wessing, A.: Fluoreszenzangiographie der Retina. Stuttgart: Georg Thieme 1968.

Dr. D. Pometta P.D.

Hôpital Cantonal

Clinique Universitaire de Médecine CH-1200 Genève 